\title{
Kadar 25-Hydroxyvitamin D Sebagai Penanda Sepsis pada Anak
}

Austin Simon Tjowanta, Chairul Yoel, Munar Lubis

Departemen Ilmu Kesehatan Anak Fakultas Kedokteran Universitas Sumatera Utara/RSUP Haji Adam Malik, Medan

Latar belakang. Sepsis merupakan penyebab tersering morbiditas dan mortalitas pada anak. Vitamin D memiliki peran penting dalam mengoptimalkan sistem imun bawaan serta memodulasi respon imun adaptif pada sepsis.

Tujuan. Untuk mengevaluasi nilai diagnostik dari kadar 25-hydroxyvitamin D sebagai penanda sepsis pada anak.

Metode. Penelitian diagnostik dengan desain potong lintang dilakukan terhadap 50 anak di PICU RSUP Haji Adam Malik dari Februari sampai Maret 2016. Duapuluh lima anak didiagnosis sepsis dan 25 non sepsis. Kriteria inklusi adalah pasien anak berusia

1 bulan sampai $<18$ tahun. Sensitivitas, spesifisitas, nilai duga positif, nilai duga negatif, rasio kemungkinan positif dan negatif dinilai pada penelitian ini.

Hasil. Rerata kadar 25-hydroxyvitamin D pada kelompok sepsis $(24 \mathrm{ng} / \mathrm{mL})$ relatif lebih rendah dibandingkan dengan kelompok non sepsis $(29,7 \mathrm{ng} / \mathrm{mL})$. Nilai batas ambang kadar 25-hydroxyvitamin D $24 \mathrm{ng} / \mathrm{mL}$. Kami menemukan 15 orang dengan sepsis dan 2 orang non sepsis dengan nilai batas ambang ini. Dari uji diagnostik diperoleh sensitivitas $60 \%$, spesifisitas $92 \%$, nilai duga positif $88 \%$, nilai duga negatif $70 \%$, rasio kemungkinan positif 7,5 dan rasio kemungkinan negatif 0,43 .

Kesimpulan. Kadar 25-hydroxyvitamin D mempunyai spesifisitas yang tinggi dan sensitivitas yang rendah sehingga dapat digunakan sebagai penanda sepsis tambahan pada anak. Sari Pediatri 2017;19(3):150-5

Kata kunci: 25-hydroxyvitamin D, sepsis, anak

\section{5-Hydroxyvitamin D Level as a Marker of Sepsis in Children}

Austin Simon Tjowanta, Chairul Yoel, Munar Lubis

Background. Sepsis is the major cause of morbidity and mortality among children. Vitamin D plays an important roles in optimazing the innate immune system and the adaptive immune response in sepsis.

Objective. To evaluate diagnostic values of 25-hydroxyvitamin D level as a marker for sepsis in children.

Methods. A diagnostic study with cross-sectional design was conducted in 50 children, 25 with sepsis and 25 without sepsis in the PICU, Haji Adam Malik Hospital from February to March 2016. Children aged 1 month to <18 years were included. Sensitivity, specificity, positive predictive value, negative predictive value, positive likelihood ratio, and negative likelihood ratio were evaluated in this study.

Results. The mean level of 25-hydroxyvitamin D in the sepsis group (24 ng/mL) was lower than in the non-sepsis group (29.7 ng/ $\mathrm{mL}$ ). The 25-hydroxyvitamin D level had a cut-off point of $24 \mathrm{ng} / \mathrm{mL}$. Using this cut-off point, we identified 15 patients with sepsis and 2 patients without sepsis. The diagnostic study showed $60 \%$ sensitivity, $92 \%$ specificity, $88 \%$ positive predictive value, $70 \%$ negative predictive value, 7.5 positive likelihood ratio, and 0.43 negative likelihood ratio.

Conclusion. The 25-hydroxyvitamin D level has high specificity but low sensitivity, for it can be used as additional sepsis marker in children. Sari Pediatri 2017;19(3):150-5

Keywords: 25-hydroxyvitamin D, sepsis, children

Alamat korespondensi: Dr. Austin Simon Tjowanta, Sp.A. Departemen Ilmu Kesehatan Anak Fakultas Kedokteran Universitas Sumatera Utara, Jl. Dr. Mansyur No.66, Medan. Email: austin.simon10@gmail.com 
S epsis adalah systemic inflammatory response syndrome (SIRS) yang disertai dugaan atau bukti ditemukan infeksi. ${ }^{1}$ Sepsis merupakan penyebab tersering morbiditas dan mortalitas pada anak. ${ }^{1,2}$ Penelusuran rekam medik internal Divisi Pediatrik Gawat Darurat Departemen Ilmu Kesehatan Anak Rumah Sakit Cipto Mangunkusumo tahun 2009 menemukan persentase kejadian sepsis 19,3\% dari 502 pasien anak yang dirawat di Pediatric Intensive Care Unit (PICU) dengan angka mortalitas $10 \% .^{3}$ Banyak anak dirawat di ruang rawat intensif anak dengan infeksi serius atau dengan peluang yang besar tertular infeksi nosokomial saat dirawat. Sepsis berat memiliki morbiditas dan mortalitas yang tinggi. ${ }^{4}$ Karena kesulitan dalam menegakkan sepsis, banyak penanda sedang dicari untuk mendiagnosis dini sepsis. Penanda inflamasi mungkin suatu saat akan terbukti lebih objektif dan dapat diandalkan daripada variabel fisiologis. Peningkatan laju endap darah, C-reactive protein, interleukin-6, dan prokalsitonin telah dilaporkan sebagai penanda potensial SIRS. Meskipun beberapa penanda sensitif, tidak satupun penanda ini dapat diandalkan karena spesifisitas yang kurang sehingga tidak cepat mengidentifikasi anak yang terinfeksi. Diagnosis dini sangat penting untuk sepsis pada anak karena sepsis bisa lebih fatal pada anak dibandingkan pada orang dewasa. ${ }^{1,5}$

Vitamin D berperan penting dalam banyak fungsi fisiologis yang berbeda. Banyak penelitian telah difokuskan pada peran baru vitamin $\mathrm{D}$ dalam metabolisme glukosa, fungsi endotel, dan modulasi sistem imun. ${ }^{6,7}$ Peran penting vitamin D dalam sistem imun manusia pada awalnya ditunjukkan dengan ditemukannya reseptor vitamin $\mathrm{D}$ di hampir semua tipe sel imun, termasuk CD4+ dan CD8+ dari sel T yang teraktivasi, sel B, neutrofil, makrofag, dan sel dendritik. Vitamin D berperan penting dalam mengoptimalkan fungsi dari sistem imun bawaan dengan menginduksi peptida antimikroba (cathelicidin dan defensin- $\beta$ ) dalam sel epitel, neutrofil, dan makrofag serta memodulasi respon imun adaptif. Cathelicidin dan defensin- $\beta$ memiliki aktivitas antimikroba yang luas terhadap bakteri Gram positif dan Gram negatif, serta virus tertentu dan jamur. Untuk imunitas adaptif, vitamin D memengaruhi proliferasi dan diferensiasi sel T dan B serta memodulasi produksi imunoglobulin. ${ }^{6,8,9}$ Di dalam tubuh manusia, 25-hydroxyvitamin D $(25(\mathrm{OH}) \mathrm{D})$ adalah metabolit utama dari vitamin D. ${ }^{10}$ Kadar $25(\mathrm{OH}) \mathrm{D}$ adalah penanda status vitamin
D yang banyak digunakan karena dianggap paling mewakili kadar total dari vitamin D dalam tubuh. ${ }^{11,12}$ Tujuan dari penelitian ini adalah untuk mengevaluasi nilai diagnostik dari kadar 25-hydroxyvitamin D sebagai penanda sepsis pada anak.

\section{Metode}

Sebuah penelitian diagnostik prospektif dengan desain potong lintang diikuti oleh 50 pasien anak yang dirawat di PICU RSUP Haji Adam Malik dari Februari sampai Maret 2016, 25 anak didiagnosis sepsis dan 25 non sepsis. Subjek dikumpulkan secara consecutive sampling. Kriteria sepsis berdasarkan hasil konferensi internasional tentang konsensus sepsis pada anak (international pediatric sepsis consensus conference) pada tahun 2005 meskipun baku emas untuk diagnosis sepsis adalah kultur darah. ${ }^{1,13}$ Gizi kurang didefinisikan sebagai berat badan menurut panjang badan atau berat badan menurut tinggi badan antara -3 dan -2 skor-z grafik pertumbuhan WHO untuk anak berusia $<5$ tahun atau berat badan menurut tinggi badan antara $70 \%$ dan 90\% grafik pertumbuhan CDC untuk anak berusia $\geq 5$ tahun. ${ }^{14}$ Anak yang berusia 1 bulan sampai $<18$ tahun diikutsertakan. Pasien dengan rakhitis, obesitas, fibrosis kistik, diabetes mellitus, hiperparatiroidisme, sindrom usus pendek, tuberkulosis, penyakit hati kronik, sindrom nefrotik, penyakit ginjal kronik, atau mengonsumsi obat-obatan yang memengaruhi kadar 25-hydroxyvitamin D dieksklusi.

Sampel darah anak yang menderita sepsis (kelompok sepsis) atau non sepsis (kelompok kontrol) diambil pada saat masuk atau hari pertama rawat. Pemeriksaan laboratorium, seperti darah lengkap, prokalsitonin (PCT), kadar 25-hydroxyvitamin D, dan kultur dilakukan di RSUP Haji Adam Malik. Kadar 25-hydroxyvitamin D diukur dengan menggunakan alat VIDAS $25 \mathrm{OH}^{\circ}$ Vitamin D Total. Penelitian ini disetujui oleh Komite Etik Penelitian Fakultas Kedokteran Universitas Sumatera Utara. Semua subjek penelitian mendapat persetujuan dari orang tua setelah dilakukan penjelasan terlebih dahulu mengenai kondisi penyakit yang dialami, dan pemeriksaan yang akan dilakukan.

Data deskriptif dinyatakan sebagai rerata (simpangan baku). Kami menggunakan kurva receiver operating characteristic (ROC) untuk mengetahui nilai batas ambang kadar 25-hydroxyvitamin D sebagai 
penanda sepsis. Uji diagnostik dengan menggunakan sensitivitas (Sn), spesifisitas (Sp), nilai duga positif (NDP), nilai duga negatif (NDN), rasio kemungkinan positif (RKP) dan rasio kemungkinan negatif (RKN). Nilai $p<0,05$ dianggap bermakna secara statistik. Analisis statistik dilakukan dengan menggunakan SPSS versi 20.

\section{Hasil}

Karakteristik demografik yang tidak jauh berbeda antara kelompok non sepsis dan sepsis berupa rerata usia, jenis kelamin, dan status gizi. Jumlah anak lakilaki lebih banyak daripada anak perempuan pada kedua kelompok (Tabel 1).

Rerata dari hemoglobin dan trombosit yang tidak jauh berbeda antara kedua kelompok, tetapi rerata dari leukosit dan prokalsitonin lebih tinggi pada kelompok sepsis daripada kelompok non sepsis. Rerata dari kadar $25(\mathrm{OH}) \mathrm{D}$ pada kelompok sepsis relatif lebih rendah dibandingkan dengan kelompok non sepsis. Pada kelompok non sepsis, semua kultur darah negatif, sedangkan pada kelompok sepsis dijumpai kultur darah positif 6 orang (Tabel 2). Dari 6 pasien sepsis dengan kultur darah positif, didapatkan hasil kultur darah Klebsiella pneumoniae pada 3 anak, Staphylococcus epidermidis pada 2 anak, dan Staphylococcus haemolyticus pada 1 anak.

Didapatkan luas area di bawah kurva ROC untuk kadar 25(OH)D sebesar 0,72 (p=0,009) (Gambar 1). Nilai batas ambang $24 \mathrm{ng} / \mathrm{mL}$ (kadar $25(\mathrm{OH}) \mathrm{D} \leq 24$ $\mathrm{ng} / \mathrm{mL}$ ) sebagai batas kadar 25-hydroxyvitamin D

Tabel 1. Karakteristik demografik subjek penelitian

\begin{tabular}{lcc}
\hline Variabel & $\begin{array}{c}\text { Non sepsis } \\
(\mathrm{n}=25)\end{array}$ & $\begin{array}{c}\text { Sepsis } \\
(\mathrm{n}=25)\end{array}$ \\
\hline $\begin{array}{l}\text { Usia, tahun, rerata }(\mathrm{SB}) \\
\text { Jenis kelamin, } \mathrm{n}\end{array}$ & $6,7(5,78)$ & $6,3(5,58)$ \\
$\quad$ Laki-laki & 14 & 15 \\
$\quad$ Perempuan & 11 & 10 \\
Status gizi, n & & \\
$\quad$ Kurang & 15 & 10 \\
$\quad$ Normal & 10 & 15 \\
\hline
\end{tabular}

Tabel 2. Hasil laboratorium subjek penelitian

\begin{tabular}{lcc}
\hline Variabel & $\begin{array}{c}\text { Non sepsis } \\
(\mathrm{n}=25)\end{array}$ & $\begin{array}{c}\text { Sepsis } \\
(\mathrm{n}=25)\end{array}$ \\
\hline Hemoglobin, g/dL, rerata (SB) & $11,7(2,44)$ & $10,6(2,89)$ \\
Leukosit, $/ \mathrm{mm}^{3}$, rerata (SB) & $10.568(4.370)$ & $23.317(17.451)$ \\
Trombosit, $/ \mathrm{mm}^{3}$, rerata (SB) & $331.200(140.537)$ & $291.960(235.638)$ \\
PCT, ng/mL, rerata (SB) & $0,3(0,34)$ & $25,9(52,05)$ \\
25(OH)D, ng/mL, rerata (SB) & $29,7(6,87)$ & $24(12,81)$ \\
Kultur darah, n & & \\
$\quad$ Positif & 0 & 6 \\
$\quad$ Negatif & 25 & 19 \\
\hline
\end{tabular}

Tabel 3. Nilai diagnostik kadar 25-hydroxyvitamin D

\begin{tabular}{|c|c|c|c|c|c|c|c|c|}
\hline \multirow{2}{*}{$\begin{array}{l}\text { Kadar } 25(\mathrm{OH}) \mathrm{D} \\
\quad \leq 24 \mathrm{ng} / \mathrm{mL}\end{array}$} & \multicolumn{2}{|c|}{ Sepsis } & \multirow{2}{*}{$\begin{array}{l}\text { Sn } \\
(\%)\end{array}$} & \multirow{2}{*}{$\begin{array}{l}\text { Sp } \\
(\%)\end{array}$} & \multirow{2}{*}{$\begin{array}{c}\text { NDP } \\
(\%)\end{array}$} & \multirow{2}{*}{$\begin{array}{l}\text { NDN } \\
(\%)\end{array}$} & \multirow{2}{*}{ RKP } & \multirow{2}{*}{ RKN } \\
\hline & $\mathrm{Ya}$ & Tidak & & & & & & \\
\hline Ya, n & 15 & 2 & 60 & 92 & 88 & 70 & 7,5 & 0,43 \\
\hline Tidak, n & 10 & 23 & & & & & & \\
\hline $\begin{array}{l}\text { Sn: sensitivitas } \\
\text { Sp: spesifisitas }\end{array}$ & & $\begin{array}{l}\text { : nilai } \\
\text { N: nilai }\end{array}$ & $\begin{array}{l}\text { positi } \\
\text { negat }\end{array}$ & & $\begin{array}{l}\text { RKP } \\
\text { RKN }\end{array}$ & o kem & kinan & ratif \\
\hline
\end{tabular}




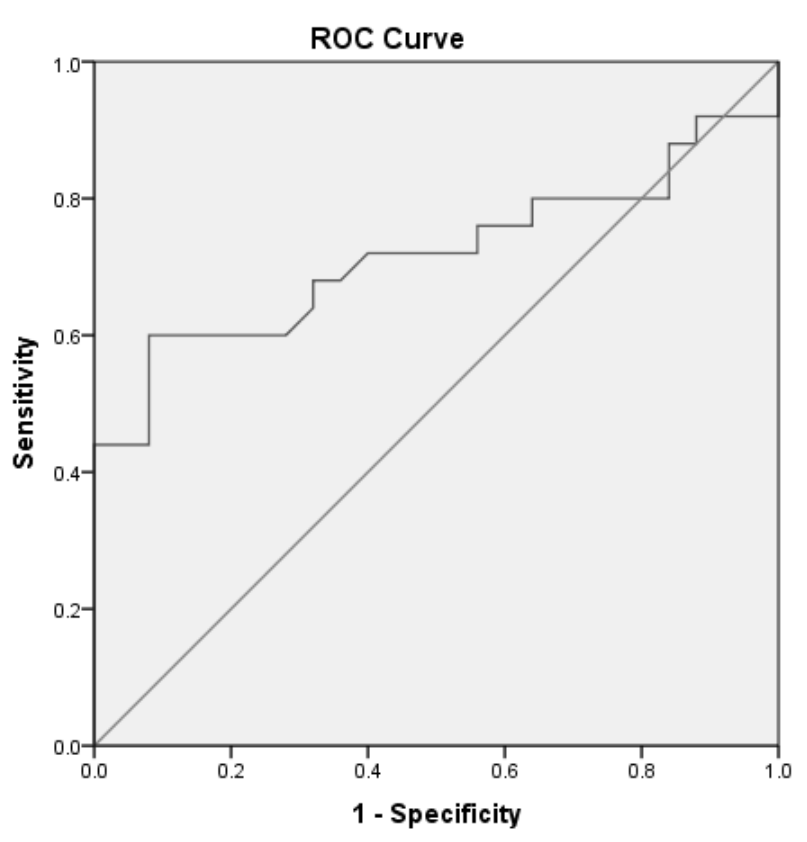

Diagonal segments are produced by ties.

Gambar 1. Kurva ROC kadar 25-hydroxyvitamin D

untuk diagnosis sepsis.

Kadar 25-hydroxyvitamin D $\leq 24 \mathrm{ng} / \mathrm{mL}$ pada kelompok sepsis dan non sepsis ditemukan 15 dan 2 orang. Dengan nilai batas ambang kadar 25-hydroxyvitamin D sebesar $24 \mathrm{ng} / \mathrm{mL}$ diperoleh sensitivitas $60 \%$, spesifisitas $92 \%$, nilai duga positif $88 \%$, nilai duga negatif $70 \%$, rasio kemungkinan positif 7,5 dan rasio kemungkinan negatif 0,43 (Tabel 3).

\section{Pembahasan}

Sepsis berhubungan dengan fungsi imun tubuh yang abnormal sebagai respons terhadap invasi patogen. Sepsis dapat terjadi melalui penyebaran langsung patogen ke dalam aliran darah. Saat patogen menginvasi aliran darah, respons tubuh terhadap patogen dimediasi oleh sistem imun bawaan dan adaptif. ${ }^{15-17}$ Vitamin D memainkan peran penting dalam sistem imun bawaan dan respons imun adaptif. Imunitas yang dimediasi vitamin D juga bermanfaat untuk membatasi aktivitas antibakteri, sehingga mencegah kerusakan yang timbul dari reaksi imun yang berlebihan. ${ }^{6,18,19}$

Dijumpai rerata kadar $25(\mathrm{OH}) \mathrm{D}$ pada kelompok sepsis $24 \mathrm{ng} / \mathrm{mL}$ dan kelompok non sepsis 29,7 ng/ $\mathrm{mL}$. Kedua kelompok berada dalam kondisi insufisiensi vitamin D. Hal tersebut berbeda dibandingkan dengan penelitian sebelumnya di Mesir yang melaporkan rerata kadar 25(OH)D pada kelompok sepsis dalam kondisi insufisiensi vitamin D $(24,5 \mathrm{ng} / \mathrm{mL})$, sedangkan tidak demikian pada kelompok non sepsis $(54,3 \mathrm{ng} / \mathrm{mL}){ }^{20}$ Perbedaan ini terjadi karena prevalensi anak yang kekurangan vitamin D di Indonesia lebih besar (44\%) dibandingkan dengan di Mesir (15\%). ${ }^{21,22}$

Pada penelitian di India ${ }^{23}$ (2013), rerata dari usia pasien anak dengan sepsis adalah 4,2 tahun dan median kadar calcifediol 19,7 ng/mL dengan prevalensi pasien sepsis yang mempunyai kadar calcifediol $<20 \mathrm{ng} / \mathrm{mL}$ lebih tinggi (51\%) dibandingkan dengan kontrol (17\%). Penelitian di Mesir ${ }^{20}$ (2015) menunjukkan rerata dari usia pasien anak dengan sepsis adalah 8 tahun dan rerata dari kadar calcifediol $24,5 \mathrm{ng} / \mathrm{mL}$. Ditemukan adanya hubungan antara sepsis pada anak dengan kadar calcifediol $<30 \mathrm{ng} / \mathrm{mL}$ ( $75 \%$ pasien sepsis dengan kadar calcifediol yang rendah) dan juga kadar cathelicidin yang rendah. Pada penelitian kami, rerata dari usia pasien anak dengan sepsis adalah 6,3 tahun dan rerata dari kadar calcifediol $24 \mathrm{ng} / \mathrm{mL}$. Jumlah pasien sepsis yang mempunyai kadar calcifediol $\leq 24$ $\mathrm{ng} / \mathrm{mL}$ lebih tinggi dibandingkan dengan kontrol. Terjadi perbedaan kadar calcifediol karena pada penelitian kami digunakan nilai batas ambang terbaik kadar calcifediol sebagai penanda sepsis (kurva ROC), sedangkan pada penelitian di India dan Mesir bukan merupakan uji diagnostik penanda sepsis.

Insufisiensi vitamin $\mathrm{D}$ sangat sering terjadi pada pasien sepsis. Bukti temuan epidemiologis telah menunjukkan bahwa insufisiensi vitamin D adalah faktor risiko terjadinya sepsis. ${ }^{24,25}$ Pada pasien sepsis, protein pengikat vitamin D (Gc-globulin) selain berfungsi sebagai pembawa calcifediol dan calcitriol juga berfungsi mengikat actin monomer sehingga mencegah polimerisasi menjadi F-actin. Polimerisasi actin yang dilepaskan oleh jaringan cedera pada sepsis akan menimbulkan agregasi trombosit sehingga terjadi emboli mikro pada end-organs. Hal inilah yang dicegah oleh Gc-globulin. Actin yang berikatan dengan Gcglobulin menyebabkan kadar Gc-globulin berkurang sehingga vitamin $\mathrm{D}$ dan metabolitnya terbuang melalui ginjal dan hal inilah yang menjelaskan terjadinya insufisiensi vitamin D pada sepsis. ${ }^{24,26}$

Hasil yang bertentangan didapatkan dalam penelitian di Turki (2014) yang melaporkan bahwa terjadi peningkatan kadar 25-hydroxyvitamin D pada anak yang didiagnosis sepsis dengan nilai batas 
ambang kadar 25-hydroxyvitamin D sebesar $20 \mathrm{ng} / \mathrm{mL}$ (sensitivitas $84 \%$ dan spesifisitas 76\%). Peningkatan kadar 25-hydroxyvitamin D pada sepsis untuk memicu produksi peptida antimikroba yang berperan pada sistem pertahanan tubuh. ${ }^{5}$ Terjadi perbedaan antara penelitian kami (kadar 25-hydroxyvitamin D $\leq 24$ ng/mL dikatakan sepsis) dengan di Turki (kadar 25-hydroxyvitamin $\mathrm{D}>20 \mathrm{ng} / \mathrm{mL}$ dikatakan sepsis). Perbedaan tersebut disebabkan kriteria sepsis yang dipakai pada penelitian di Turki menggunakan kriteria sepsis neonatus, sedangkan subjek penelitian kami bukan neonatus. Demikian juga pasien sepsis dengan kultur darah negatif dieksklusi, sedangkan tidak semua pasien sepsis didapatkan kultur darah positif. Hal inilah yang mungkin membuat perbedaan hasil kadar 25-hydroxyvitamin D dibandingkan dengan penelitian kami.

Penelitian yang lain di Turki ${ }^{27}$ (2015) melaporkan bahwa $84 \%$ dari neonatus pada kelompok sepsis memiliki kadar 25-hydroxyvitamin $\mathrm{D}<11 \mathrm{ng} / \mathrm{mL}$ (rerata dari kadar calcifediol 8,6 ng/mL) yang berarti neonatus dengan defisiensi vitamin $\mathrm{D}$ mempunyai hubungan dengan peningkatan risiko terjadinya sepsis. Kadar calcifediol yang berbeda dengan penelitian kami disebabkan usia yang berbeda dan kadar calcifediol pada neonatus dipengaruhi kadar calcifediol ibu, sedangkan kadar calcifediol pada anak dipengaruhi paparan terhadap sinar matahari.

Hasil studi kami juga menunjukkan bahwa kadar $25(\mathrm{OH}) \mathrm{D}$ mempunyai sensitivitas $60 \%$ yang berarti kadar 25(OH)D dapat mengklarifikasi anak yang menderita sepsis sebesar 60\%. Spesifisitas 92\% yang berarti kadar 25(OH)D dapat mengklarifikasi anak yang tidak menderita sepsis sebesar $92 \%$. Meskipun dengan sensitivitas yang rendah, kadar $25(\mathrm{OH})$ D mempunyai spesifisitas yang tinggi sehingga nilai diagnostiknya masih dapat digunakan untuk mengidentifikasi pasien anak yang tidak sepsis. Nilai duga positif $88 \%$ menunjukkan bahwa kadar $25(\mathrm{OH})$ $\mathrm{D}$ dapat memprediksi anak yang menderita sepsis sebesar $88 \%$ dan nilai duga negatif $70 \%$ menunjukkan bahwa kadar 25(OH)D dapat memprediksi anak yang tidak menderita sepsis sebesar 70\%. Rasio kemungkinan positif 7,5 berarti peningkatan moderat kemungkinan pasien sepsis dan rasio kemungkinan negatif 0,43 berarti penurunan kecil kemungkinan pasien sepsis.

Kelebihan dari penelitian ini adalah merupakan uji diagnostik dengan menilai sensitivitas, spesifisitas, nilai duga positif, nilai duga negatif, rasio kemungkinan positif dan rasio kemungkinan negatif serta nilai batas ambang kadar 25-hydroxyvitamin D untuk diagnosis sepsis yang didapat dengan menilai kurva ROC sehingga evaluasi nilai diagnostik kadar 25-hydroxyvitamin D dilakukan dengan tepat. Kelemahan dari penelitian ini adalah ukuran sampel yang kecil dan hanya dilakukan di satu rumah sakit sehingga dapat mengurangi representasi dari kasus sepsis dan hasil uji diagnostik.

\section{Kesimpulan}

Kadar 25-hydroxyvitamin D mempunyai spesifisitas yang tinggi dan sensitivitas yang rendah sehingga dapat digunakan sebagai penanda sepsis tambahan pada anak.

\section{Daftar pustaka}

1. Goldstein B, Giroir B, Randolph A. International pediatric sepsis consensus conference: Definitions for sepsis and organ dysfunction in pediatrics. Pediatr Crit Care Med 2005;6:2-8.

2. Watson RS, Carcillo JA, Linde-Zwirble WT, Clermont G, Lidicker J, Angus DC. The epidemiology of severe sepsis in children in the United States. Am J Respir Crit Care Med 2003;167:695-701.

3. Saraswati DD, Pudjiadi AH, Djer MM, Supriyatno B, Syarif DR, Kurniati N. Faktor risiko yang berperan pada mortalitas sepsis. Sari Pediatri 2014;15:281-8.

4. Hebbar KB, Wittkamp M, Alvarez JA, McCracken CE, Tangpricha V. Vitamin D deficiency in pediatric critical illness. J Clin Transl Endocrinol 2014;1:170-5.

5. Aydemir G, Cekmez F, Kalkan G, dkk. High serum 25-hydroxyvitamin $\mathrm{D}$ levels are associated with pediatric sepsis. Tohoku J Exp Med 2014;234:295-8.

6. Kempker JA, Han JE, Tangpricha V, Ziegler TR, Martin GS. Vitamin D and sepsis: An emerging relationship. Dermatoendocrinol 2012;4:101-8.

7. Holick MF, Binkley NC, Bischoff-Ferrari HA, dkk. Evaluation, treatment, and prevention of vitamin D deficiency: An endocrine society clinical practice guideline. J Clin Endocrinol Metab 2011;96:1911-30.

8. Prietl B, Treiber G, Pieber TR, Amrein K. Vitamin D and immune function. Nutrients 2013;5:2502-21.

9. Hewison M. Vitamin D and the immune system: New perspectives on an old theme. Endocrinol Metab Clin North Am 2010;39:365-79. 
10. Walker VP, Modlin RL. The vitamin D connection to pediatric infections and immune function. Pediatr Res 2009;65:106R-13R.

11. Ganji V, Zhang X, Tangpricha V. Serum 25-hydroxyvitamin $\mathrm{D}$ concentrations and prevalence estimates of hypovitaminosis D in the U.S. population based on assay-adjusted data. J Nutr 2012;142:498-507.

12. Looker AC, Pfeiffer CM, Lacher DA, Schleicher RL, Picciano MF, Yetley EA. Serum 25-hydroxyvitamin D status of the US population: 1988-1994 compared with 2000-2004. Am J Clin Nutr 2008;88:1519-27.

13. Liesenfeld O, Lehman L, Hunfeld KP, Kost G. Molecular diagnosis of sepsis: New aspects and recent developments. Eur J Microbiol Immunol 2014;4:1-25.

14. Sjarif DR. Prinsip Asuhan Nutrisi pada Anak. Dalam: Sjarif DR, Lestari ED, Mexitalia Maria, Nasar SS, penyunting. Buku Ajar Nutrisi Pediatrik dan Penyakit Metabolik. Edisi pertama. Jakarta: Ikatan Dokter Anak Indonesia; 2011.h.36-48.

15. Aziz M, Jacob A, Yang WL, Matsuda A, Wang P. Current trends in inflammatory and immunomodulatory mediators in sepsis. J Leukoc Biol 2013;93:329-42.

16. Cai B, Deitch EA, Ulloa L. Novel insights for systemic inflammation in sepsis and hemorrhage. Mediators Inflamm 2010:2010;1-10.

17. Lever A, Mackenzie I. Sepsis: definition, epidemiology, and diagnosis. BMJ 2007;335:879-83.

18. Adams JS, Hewison M. Unexpected actions of vitamin D: New perspectives on the regulation of innate and adaptive immunity. Nat Clin Pract Endocrinol Metab 2008;4:80-90.

19. Sadeghi K, Wessner B, Laggner U, dkk. Vitamin D3 down-regulates monocyte TLR expression and triggers hyporesponsiveness to pathogen-associated molecular patterns. Eur J Immunol 2006;36:361-70.

20. Ismail AM, Abdelrahman SH, Elsayed AH, Alkheshen GA, Sadaney MAE. A study of vitamin D status and cathelicidine plasma levels in pediatric population with sepsis. J Am Sci 2015;11:1-6.

21. Sandjaja S, Budiman B, Harahap H, dkk. Food consumption and nutritional and biochemical status of 0.5-12-yearold Indonesian children: the SEANUTS study. Br J Nutr 2013;110:S11-20.

22. Shady MMA, Youssef MM, El-Din EMS, dkk. Predictors of serum 25-hydroxyvitamin D concentrations among a sample of Egyptian schoolchildren. Scientific World Journal 2016;2016:8175768.

23. Satheesh P, Verma S, Singhi S, Bansal A. Prevalence of vitamin $\mathrm{D}$ deficiency among children with sepsis, its association with sepsis severity and its outcome in a pediatric ICU. Crit Care 2013;17:35.

24. Jeng L, Yamshchikov AV, Judd SE, dkk. Alterations in vitamin $\mathrm{D}$ status and anti-microbial peptide levels in patients in the intensive care unit with sepsis. J Transl Med 2009;7:28.

25. Grant WB. Solar ultraviolet-B irradiance and vitamin D may reduce the risk of septicemia. Dermatoendocrinol 2009;1:37-42.

26. Meier U, Gressner O, Lammert F, Gressner AM. Gc-Globulin: Roles in response to injury. Clin Chem 2006;52:1247-53.

27. Cetinkaya M, Cekmez F, Buyukkale G, Ercan TE, Demir F, Tunc T. Lower vitamin D levels are associated with increased risk of early-onset neonatal sepsis in term infants. J Perinatol 2015;35:39-45. 